\title{
Torwegian emigration and the emergence of modernity in Norway: America letters and the cases of Knut Hamsun and Sigbjørn Obstfelder
}

\section{Ioana-Andreea Mureșan}

Babeș-Bolyai University, Department of Scandinavian Languages and Literatures, Email: ioana.muresan (at) lett.ubbcluj.ro

\begin{abstract}
Norway was going through important changes in the 19th century. It was a time of disruption, when the old rural society was transformed by the growing industrialisation, by the development of transportation and the expansion of free trade, when internal migration reached its peak as farmers struggled to survive using the old ways of living that had been passed on from generations and that no longer seemed to work in the modernized world. This paper argues that, although the need for change of the old habits was at the basis of the mass exodus to the New World, migration facilitated the emergence of modernity in Norway. America letters played an important role, as they both convinced the families and friends of the emigrants to embark for America, but they also helped increase the literacy rate in the homeland. Further on, the discussion will focus on the American experience of Knut Hamsun and Sigbjørn Obstfelder, which helped them gain recognition as forerunners of modernism in Norway.
\end{abstract}

Keywords: Norwegian emigration; America Norway; homeland; immigrant experience; modernity; America letters; Knut Hamsun; Sigbjørn Obstfelder

CC BY-SA License (https://creativecommons.org/licenses/by-sa/2.0)

This paper has been presented at the Eleventh International Conference on Baltic and Nordic Studies in Romania: ReThinking Europe in Scandinavia and the Baltic Sea region, hosted by the Romanian Association for Baltic and Nordic Studies, May 28-29, 2020. 


\section{Introduction}

America was rediscovered by the European emigrants in times of turmoil, when the world was going through earth-shaking changes that affected all layers of societies. The $19^{\text {th }}$ century and the beginning of the $20^{\text {th }}$ century witnessed the mass migration of the peoples of Europe eager to change their luck and have their share of opportunities in the New World. The Potato Famine from 1845-1849 drove the Irish away from the fatherland, and it became a catalyst for the mass migration to America. Furthermore, the revolutions of 1848 generated stirs, but also brought disillusionment for numerous Europeans who refused to remain in enclosed societies. At the same time, the California Gold Rush made the eyes of hundreds of thousands sparkle, attracting them from across America and abroad between 1849 and 1855. As industrialization grew more and more visible, steamships replaced sailing ships in the 1880s, and made the transatlantic voyage far more appealing due to reduced duration and fares. After the British Isles, Ireland, Germany, and Scandinavia, from whence the first two significant immigrant waves occurred, Southern and Eastern Europe sent the third wave, between 1880 and 1914, when more than 20 million Europeans emigrated to the United States of America.

The Norwegian emigration to America in the $19^{\text {th }}$ and $20^{\text {th }}$ centuries was the second largest from Europe; only the Irish were more numerous if we consider the population of the two countries. Even though the 1800s and the first decade of the $20^{\text {th }}$ century brought significant improvements in the life of the growing Norwegian people, the progress was slow and people's expectations high, so it was natural that old means of livelihood had to be abandoned, as young people did not want to continue in the trades of their parents. There was a spirit of change -a wish for change, and the necessity for it.

This paper argues that the Norwegian emigration to America had a strong influence on the evolution of the society in the fatherland, enhancing the emergence of modernity in Norway. America letters represent firsthand accounts that illustrate the role played by the immigrants, and the analysis of the cases of Norwegian writers Knut Hamsun and Sigbjørn 
Obstfelder comes to support the influence of their American immigrant experience on their writing.

\section{Norwegian emigration to America}

The Norwegians of the $17^{\text {th }}$ or $18^{\text {th }}$ centuries knew little about America, but this changed at the end of the $18^{\text {th }}$ and the beginning of the $19^{\text {th }}$ century, as Norwegians (under Danish rule) began to experience some economic advances, but also a revival of the national feelings since they were working to gain more freedom from the Danes and become interested in what was happening across the Atlantic Ocean ${ }^{1}$. The United States of America had gained independence from Great Britain, creating premises for other peoples to fight for freedom, and Ingrid Semmingsen underlies that the Norwegian patriots who adopted the Norwegian Constitution at Eidsvoll in 1814 felt sympathy for this distant country that had earned the right to self-determination ${ }^{2}$.

Restauration was the name of the sloop that carried in 1825 the first significant group of Norwegian immigrants to America. The fifty-two emigrants from Stavanger were adepts of Hans Nielsen Hauge, a figure that had generated a national religious movement in the fatherland because of his criticism of the church and the clergy ${ }^{3}$. The sloopers, as they were called, were by no means among the poor emigrants who were forced to leave the homeland to survive, as they had sent a scout to investigate the conditions in the New World (Cleng Peerson), had purchased the ship and had prepared the journey for several years, investing in a cargo that would bring them the necessary income to start a new life on new shores.

More than 800,000 people left Norway for America between 1825 and 1925, and the majority emigrated in the course of fifty years, from 1865 to 1915. There were three important immigrant waves: the first began in 1865 and lasted through the first years of the 1870s, the second wave started in 1879 and continued until 1893, with a record year, 1882, when

\footnotetext{
${ }^{1}$ Ingrid Semmingsen, Norway to America. A History of the Migration, Translated by Einar Haugen (Minneapolis: University of Minnesota Press, 1978), 7.

${ }^{2}$ Ibid., 8.

${ }^{3}$ Ibid., 13-14.
} 
29,000 Norwegians emigrated, while the last significant migration wave was registered at the beginning of the $20^{\text {th }}$ century, from 1903 to 1907.4

When referring to the period that registered the highest number of Norwegian immigrants to America, Semmingsen mentions the political restlessness of the time, and how it influenced the mass migration:

\begin{abstract}
The winds of change which had been only a breeze in the beginning of the century had turned into a hurricane. Not only did they breathe new ideas into the heads of those who stayed home, they also caused an exodus. Thousands went across the sea, not because they did not appreciate their homeland, but because they felt that the homeland did not appreciate them and their work, and because the old social bonds could no longer hold them. ${ }^{5}$
\end{abstract}

Hence, the period between 1865 and 1915 was so imbued with aspirations, with the need for change, that thousands and thousands of Norwegians fled the country that did not offer them the prospects inspired by the New World. Indeed, as Einar Haugen explains, Norwegians did not choose to emigrate because of the poverty, or because they were oppressed, or persecuted, although many were under-privileged, as had been their ancestors, who had accepted the difficulties as "the will of God"; the Norwegians "emigrated because they had learned to be dissatisfied, and because a changing world had provided them with hope of escape from their dissatisfaction"6. Furthermore, the mass migration and the industrialization led to a profound questioning of the traditional way of life, as well as of the traditional values. New ideas emerged, creating premises for change. And migration was an important factor in the emergence of this change. Nils Olav Østrem highlighted the impact of the mass migration to America upon the Norwegian society, and how it enhanced its development: "The emigration was not just a row with dramatic chasms, but first and foremost an important social process.

\footnotetext{
${ }^{4}$ Ibid., 99.

${ }^{5}$ Ibid., 112.

${ }^{6}$ Einar Engvald Haugen, The Norwegian language in America: a study in bilingual behavior (Bloomington: Indiana University Press, 1969), 22.
} 
Migration is a durable phenomenon with no little impact upon the society, both in our times and throughout history". ${ }^{7}$

\section{America Letters}

Migrant letters have not been explored enough, and their value as primary source in the study of migration has not been fully appreciated. These letters, especially in the $19^{\text {th }}$ century and the beginning of the $20^{\text {th }}$ century, had a significant impact on their recipients, as they contained information that was considered reliable and trustworthy by the prospective emigrants. ${ }^{8}$ Ordinary people could maintain the connection with their families and friends in the homeland, but also share their impressions about the New World through these letters. ${ }^{9}$ More than that, these personal letters were the most common and widespread means of communication for the immigrants, and this genre became "the source of wisdom about life in the new location"10 more than the booklets, newspapers or pamphlets that were available at the time. In her history of the Norwegian emigration to America, Ingrid Semmingsen mentions letter writing as a novel means of communication in the rural society of Norway, in the $1840 \mathrm{~s}^{11}$, whereas Orm Øverland highlights the fact that the mass migration from Norway to the New World stimulated literacy, creating a new need for written communication. ${ }^{12}$ We have to bear in mind the fact that most emigrants belonged to the lower classes, and that emigration

\footnotetext{
7 Own translation, original text in Norwegian: "Utvandringa var ikkje berre ei rad med dramatiske oppbrot, men først og fremst ein viktig samfunnsprosess. Migrasjon er eit varig fenomen med ikkje liten verknad for samfunnet, både i vår tid og gjennom historia", Nils Olav Østrem, Norsk utvandringshistorie (Oslo: Det Norske Samlaget, 2006), 17-18.

${ }^{8}$ Félix Krawatzek and Sasse, Gwendolyn. 'Integration and Identities: The Effects of Time, Migrant Networks, and Political Crises on Germans in the United States'. Comparative Studies in Society and History, 60(4) (2018): 1033.

${ }^{9}$ Ibid.

${ }^{10}$ Bruce S. Elliott, David A. Gerber, and Suzanne M. Sinke, 'Introduction', Letters across Borders. The Epistolary Practices of International Migrants (New York: Palgrave Macmillan, Published in association with the Carleton Centre for the History of Migration, 2006), 2.

11 Semmingsen, 1978:166.

12 Orm Øverland, The Western Home: A Literary History of Norwegian America (Northfield, Minnesota: Norwegian-American Historical Association, Distributed by University of Illinois Press, 1996), 19.
} 
made them deal with new surroundings, new challenges, and one such challenge was to preserve the relation with those left in the fatherland by means of acquiring new skills, such as reading and writing. Hence, as Øverland mentions, members of a social class that was not familiar with the use of pen and paper were transformed into letters writers by the "radical ruptures of emigration". ${ }^{13}$

Thousands of letters have been collected by historical associations, but also by historians and researchers such as Theodore C. Blegen, Solveig Zempel or Orm Øverland throughout the years, letters sent by NorwegianAmericans to their families and friends. They are known as America letters, and the role they played in the evolution of the mass migration is not to be overlooked.

Blegen, in his Land of Their Choice: The Immigrants Write Home, attaches a great value to America letters, as he mentions that "the nineteenth century witnessed a new discovery of America. It came about, not through the daring of a new Columbus, but as a consequence of letters written by immigrants to the people of the Old World. It was a progressive and widening discovery that played an important role in the migration of millions of Europeans from their home countries to the United States."14 Thus, the letters sent home by the immigrants have generated a new discovery of the New World, as they represented a bridge between individuals from the two continents, but also personal accounts of the migration story that would become the story of millions.

Most Norwegians in the $19^{\text {th }}$ century knew little to nothing about America until they received the first letters from their relatives and friends who had emigrated. These letters were their only reliable source of information, containing details about the conditions in the New World, the voyage across the Atlantic, or about what they should expect from the emigration. ${ }^{15}$ Descriptions of the opportunities that awaited emigrants in

\footnotetext{
${ }^{13}$ Ibid., 19.

14 Theodore C. Blegen, Land of Their Choice: The Immigrants Write Home (Minneapolis: The University of Minnesota Press, 1955), 3.

15 Solveig Zempel, In Their Own Words. Letters from Norwegian Immigrants (Minneapolis, London: University of Minnesota Press, The Norwegian-American Historical Association, 1991), $x$.
} 
America, of the freedom and the equality the Norwegians had found there, but also of the vast land that could be claimed were all decisive for those that had considered emigration. Moreover, these letters were written many times not only for the eyes and ears of the members of the family or friends, but for the larger community, as they were passed on from family to family, parish to parish, village to village, or even printed in newspapers. Of the early immigrants, Gjert Gregoriussen Hovland played an important role in the evolution of the Norwegian emigration, as he became a prolific letter writer after he emigrated to America in 1831. The Hovland letters gained significant attention, and were copied and sent to other communities, enticing people to emigrate. ${ }^{16}$ The spread of information through these America letters was highly important, as it encouraged emigration, especially in areas with favourable socio-economic conditions, or where the idea was already blossoming. ${ }^{17}$

America letters can be considered as a diary on a great scale, and this diary was kept by people who were experiencing a change of the worlds ${ }^{18}$, and they described the opportunities the wanderers had found in the New World, the freedoms and the economic conditions which were much better than at home. Moreover, the letters depicted emigration in a favourable tone - especially if we consider the emigrants might have wanted to confirm to their relatives that the decision to leave the homeland had been a good decision. Barbro Ramseth emigrated at the age of fifty, in 1888 , together with her husband and their five children, to Vernon County, Wisconsin, where they formed a tight community along with other friends and acquaintances from Tynset, Norway. Already in her first letter, which was written to her father, she expresses her belief that the decision to emigrate to America was a good decision:

My often remembered dear old Father,

I hope that these lines will find you in the best of health, and will let you know how we are faring. We are all in good health and like it

\footnotetext{
${ }^{16}$ Semmingsen, 1978:17.

17 Zempel, 1991:x.

${ }_{18}$ Theodore C. Blegen, 'The Immigrant Image of America', Norwegian-American Studies and Records 19 (1956): 3.
} 
here quite well, it is getting better and better all the time, so we must just hope that everything will eventually be fine. I often think of Tynset, and of you, then I long for home, but now, thank goodness, things are much better. I am fully convinced that it was best for us to come over here, for our experience shows that it is easier to earn money here, and fight our way through, but it is a painful process, many losses for a newcomer. ${ }^{19}$

Some America letters spoke more of the hardships and difficulties one might expect to find on American soil. Such is the letter written by a Norwegian woman from Finnøy, Berta Serina Bjøravåg (married Kingestad), who emigrated to Illinois in 1885. Translated by Solveig Zempel, one of her letters sent to her sister back home reveals some of the trials she was facing, without showing any sign of disillusionment or change of mind in what concerns the decision to emigrate:

As far as my own well-being is concerned, it is going better than I had expected. Naturally there are a few heavy moments now and then, that is true for all of us who have recently come over and no less for me. Yes, dear Anna, there are many trials for a poor greenhorn here in this country. When I left, I thought I knew how to work, but when I got here, I found that I didn't know the least bit, but of course I am not too old to learn. I don't have any especially hard work to carry out, it is just to keep going all day, and that is tiring enough in the long run, so I can truthfully say that I was seldom as tired when I went to bed in Norway as I am here, but I can only thank God that I have the health to be out working. It didn't look good when I first came over, but you know that it is hardest at first until you really get the hang of things. ${ }^{20}$

These letters are relevant for the study of migration not only because of their role in its evolution, but also because they kept alive the relationships between their senders and recipients, between the immigrants and those who remained in the fatherland. They had a personal significance, as they gave the immigrants the opportunity to share their thoughts and feelings

\footnotetext{
${ }^{19}$ Zempel, 1991:104.

${ }^{20}$ Ibid.:29-30.
} 
with the loved ones in their own language, making the separation less painful for both sides. ${ }^{21}$ Last, but not least, these letters provide insights into the personal stories of migration, although they do not offer the whole picture, since it is easy to understand that most migrants preferred to emphasize the positive aspects of their experience, with the purpose to entice their family and friends to join them. Most importantly, America letters are subjective and reflect the character of the immigrant writer, but they provide a different perspective than that of the historian or the novelist, as immigrants "tell their own stories in their own words" 22, expressing their hopes for a better future, for them and for their children.

\section{Knut Hamsun's America}

Young Hamsun embarked for America full of hopes, in 1882, at the age of 23. Lars Frode Larsen calls Hamsun's America voyage his third exodus, as the first uprooting of the Norwegian writer occurred already as a child, when his family was forced to move from Gudbransdalen to Northern Norway, while the second took place in 1879, when Hamsun left home for Hardanger, then Copenhagen, and eventually Christiania (Oslo) to become a writer. ${ }^{23} \mathrm{He}$ made two voyages in America, between 1882 and 1884, and between 1886 and 1888; he worked on farms, then as store clerk, construction worker, even as streetcar conductor in Chicago, but also as a lecturer and journalist. ${ }^{24}$ Larsen considers him to be the typical Norwegian immigrant, as he was a single young man, full of ambitions, though without studies, and with older family members that had emigrated; furthermore, his leaves for America in 1882, the year that registered the largest number of Norwegian immigrants. ${ }^{25}$ Upon his arrival, he is

\footnotetext{
${ }^{21}$ Ibid.: xi.

22 Ibid.: xiii.

${ }^{23}$ Lars Frode Larsen,'Knut Hamsuns «exodus〉-Amerika-Oppholdet 1882-1884' . Nordlit 13 (2003):99-100.

${ }^{24}$ Sigmund Skard, The United States in Norwegian History. Contributions in American Studies No. 26. Westport, Connecticut, London, England: Greenwood Press (Oslo: Universitetsforlaget, 1976), 116.

${ }^{25}$ Larsen, 2003:102.
} 
impressed by the towering buildings and constructions, as he describes New York to his friend Torger Kyseth in Gjøvik:

Torger, you should have been with me in New York and seen all the splendour there. The railway goes up in the air over the people's roofs, and there are thousands of telegraph and telephone wires stretching between the buildings; the bridge from New York to Brooklyn is about $3 / 4$ of a Norwegian mile long; there the railway is to go; but above that fine steel wires are formed into a net, and that is where the pedestrians are to go. That bridge is the world's biggest engineer undertaking, and it is so high that when you walk across you come up into a different layer of air, and there is a terrible wind blowing. And you should have been here to have seen the buildings. I saw buildings in New York that were 13 storeys, two of which were underground." 26

Despite the first positive impression, Hamsun experiences many hardships during the period spent in the New World. After working hard for most of his stay in America, things change for the better as the Norwegian Unitarian pastor Kristofer Janson persuades him to assist the congregation in Minneapolis, giving him the possibility to improve his English, to make translations and give lectures to the Norwegian-American community. In a letter written to his friend Sven Tveraas in April 1884, while he was living in Minneapolis, in Kristofer Janson's house, Hamsun admits that he is bitterly displeased with his life in America: "Yet I am not very content. God knows I suffer under a life like this. I feel so infinitely remote from people torn away from everything. I am melancholy to a degree" ${ }^{\prime 2}$

Hamsun did not go to the New World just as any other immigrant to seek his fortune, but he had great expectations, hoping he would find larger opportunities, and that he would be able to use his gifts, as other poets had done; however, he would be sorely disappointed..$^{28}$ After all the hardships he experienced, he still didn't succeed to earn enough money to

\footnotetext{
${ }^{26}$ Harald Næss and James McFarlane, Knut Hamsun: Selected Letters: Volume 1: 1879-98 (London: Norvik Press, 1990), 32.

27 Ibid.: 45.

${ }^{28}$ Hanna Astrup Larsen, Knut Hamsun (New York: Alfred A. Knopf, 1922), 21.
} 
support himself, and, in the summer of 1884, he learned he suffered from tuberculosis, which urged him to return to Norway with the help of the Unitarian friends in Minneapolis who paid for his travel expenses. ${ }^{29}$ As soon as he arrived in Europe, his health was restored.

Knut Hamsun's second America visit, from 1886 to 1888, begins under better auspices, as he arrives as a paid journalist that would send written reports to several Norwegian newspapers. However, the financial problems do not spare him, and he ends spending some time in Chicago, working as a streetcar conductor. In a letter he sent in September 1886 to Erik Frydenlund, the young writer complains about the struggles of finding a job:

I'm in Chicago. Well, it's not at all easy to find a 'job' here. I have now been round hundreds of places, written hundreds of applications in reply to advertisements in the Chicago Tribune, but with no luck. I began this hunt about two weeks ago. Then I thought: this is enough, damn it! So I went to work on the railroad - in the middle of Chicago's streets. ${ }^{30}$

His adventure in the Windy City is short, and he is bound to move to North Dakota, where he works for a while in a bonanza farm on the prairie. Before returning for good in the fatherland, Hamsun benefits again from the support of the Unitarian friends, he reserves Dania Hall in Minneapolis, and delivers a lecture to the Norwegian-American community in which he criticizes the American materialism, morals, and intellectual life. ${ }^{31}$

The unsuccessful attempts at becoming a writer in the fatherland, the restlessness and the desire to become a well-known writer, to bring poetry into the lives of the Norwegian immigrants in America, drove Knut Hamsun to American shores to try his luck, but he eventually had to admit that he will not succeed, especially if we think of what manual labour meant for Hamsun, who lacked practical skills, and cherished intellectual

\footnotetext{
${ }^{29}$ Arlow W. Andersen,'Knut Hamsun's America. Norwegian-American Studies 23 (1967):179.

${ }^{30}$ Næss, McFarlane, 1990:59.

${ }^{31}$ A. Andersen, 1967:181.
} 
activities and literature more than anything else. ${ }^{32}$ His American experience definitely influenced his perception of the New World, and his disappointment would be bitterly felt in the lecture he gave in 1889 at the University of Copenhagen, which he eventually developed in his book The Cultural Life of Modern America.

Arlow Andersen regards the outbursts of the young and outspoken poet that Hamsun was at the time when he wrote his account of America as more emotional than objective ${ }^{33}$, whilst Sverre Arestad calls the book a "subjective attack on American values, despite its many striking observations on cultural pretensions". ${ }^{34}$ Indeed, he described America as a country dominated by materialism and self-sufficiency, in which Yankees were always in pursuit of fortune and social influence, showing little interest in literature or arts. ${ }^{35}$ The Cultural Life of Modern America begins with Hamsun's criticism of the American patriotism, which, he says, "is fearless about the consequences of its hot-headed impetuosity. It is so arrogant that, in those people who lack a corresponding degree of intelligence, it becomes a fatuous pride. There is one country, America; anything beyond this is no good" ${ }^{36} \mathrm{He}$ is amazed at the fact that the very nation that is so taken with itself shows such poor knowledge about others ${ }^{37}$, and that the immigrants are so eager to discard their old clothes, to erase the traces of their foreign origin, and fully embrace the American way. ${ }^{38}$ Hamsun's diatribe continues with a critique of materialism, as he sees Americans all to absorbed in their pursuit of money, as all their interests revolve around it ${ }^{39}$; furthermore, in his view, the self-sufficiency of the Americans prevents them from having a real cultural life, and also from acknowledging superiority in any other

\footnotetext{
32 Ioana-Andreea Mureșan, 'Deconstructing the American Dream: America Through Knut Hamsun's Eyes'. Studia UBB Philologia, LXII (3) (2017): 151.

${ }^{33}$ A. Andersen, 1967:185.

34 Sverre Arestad, 'Hamsun and America', Norwegian-American Studies 24 (1970): 152.

${ }^{35}$ Mureșan, 2017:153.

${ }^{36}$ Knut Hamsun, The Cultural Life of Modern America, Edited and translated by Barbara Gordon Morgridge (Cambridge, Massachusetts: Harvard University Press, 1969), 8.

37 Ibid.

${ }^{38}$ Ibid.: 11.

${ }^{39}$ Ibid.: 19.
} 
culture. ${ }^{40}$ The book also tackles themes such as literature, education, and expresses his appreciation for the American journalism.

This book is relevant not merely for its truthful account of the American society and cultural life, but it needs to be read and analysed through the eyes of a young aspiring writer that had struggled with failed attempts at achieving his dream. The bitterness which transpires is a reminiscence of personal unsuccess in a country which was teeming with examples of achieving dreams, especially if we consider the large numbers of immigrants that were flooding to America at the end of the $20^{\text {th }}$ century.

Hamsun's American experience did influence his writings, and in 1903, fifteen years after his return to the Old World, he published a book of sketches dedicated to his American years, Kratskog ("Brushwood"); indeed, he did not lay emphasis on America, but treated those episodes as a part of his general experience of life. ${ }^{41}$ Furthermore, in a letter he sent to his friend Frydenlund from Copenhagen in 1889, when his book on America was printed and the sun finally began to shine on him as well, Hamsun wrote openly about the hunger he had endured: "In God's name, Erik Knudsen Frydenlund, did you but know the life I have been living! You have no idea how my guts cried out in protest sometimes. Both in America and here at home. Sometimes living for days on a meal which I may have had at the beginning of the week. Sitting there chewing matchsticks. Tough diet, my lad! Uff! Hard tack! Hell!".42 And yet, these tough experiences from Christiania and America had laid the basis for his breakthrough novel, Hunger, published in 1890.

\section{Sigbjørn Obstfelder's Disappointing American Experience}

The success story has dominated the studies of individual Norwegians in America, especially in what concerns material and professional achievement, but Sigbjørn Obstfelder's encounter with America comes to open up a new dimension, as none of the stories are as tragic as Obstfelder's story, and he represents a unique case in his

\footnotetext{
${ }^{40}$ Ibid.: 22.

${ }^{41}$ Arestad, 1970:153.

42 Næss, McFarlane, 1990:100.
} 
relationship to the American scene..$^{43}$ Born in 1866, in Stavanger, Obstfelder had dreamt of becoming a musician, of expressing the inexpressible. ${ }^{44}$ With many wanderings and trials, "his life was a restless and usually planless migration, in fear of life, in the hope of meeting happiness". 45

He started to study engineering with the hope he would find a job in America, where his brother Herman had emigrated, so, in the summer of 1890, Sigbjørn joined his brother in Milwaukee, and worked as draughtsman, moving to the Chicago area several months afterwards. In a letter he sent to Herman in March 1891, Obstfelder complains about his situation in Chicago:

Well, what shall I write about. My mind is enveloped in an impenetrable veil of sadness. This place seems unbearable to me. I can't talk to any of the people - I can't go home. My debt has to be paid. And my work. As I've said before, it stifles me. For it gives me time to think and ponder and yearn for all that I want. The only thing that keeps me going, and which pursues me when I go to bed and when I get up, and when I have a respite, is my determination to leave here and get some kind of surveying job as soon as possible. [...] I repeat; a more desolate place I've never been in, hardly think it exists. ${ }^{46}$

Obstfelder did not exactly know why he came to America, perhaps he sought there some meaning, some significance for a life that did not seem to have any meaningful future at home. ${ }^{47}$ Another letter, written in April 1891, exposes bot his discontent with his life in Chicago and his anxiety over his future:

\footnotetext{
${ }^{43}$ Sverre Arestad, 'Sigbjørn Obstfelder and America'. Norwegian-American Studies 29 (1983): 254.

${ }^{44}$ Harald Beyer, A History of Norwegian Literature, Translated and edited by Einar Haugen (New York: New York University Press for the American-Scandinavian Foundation, Fourth printing, 1979), 263.

${ }^{45}$ Ibid.

${ }^{46}$ Arestad, 1983:271-272.

${ }^{47}$ Arestad, 1970:150.
} 
Things are getting worse and worse with me. If it had not been for that debt of mine at home, I would have been gone from here long ago. I am unable to describe how dreary, deadly it is here, and how mortally tedious the people are that I of necessity must look at every day. No one to talk to, no one I care to talk to. And then the worst of all: since I came to Was. Heights I have become certain in my seclusion what I ought to do. The first or the second night here at W. H. I lay awake the whole night and in the morning I was sure that I wanted to stake everything on becoming a musician, a composer. [...] I know now that I would gladly live in poverty, if I could devote myself to this, which is my calling. Therefore I wrote: My fate is in God's hands. ${ }^{48}$

Upon his return to Stavanger, in 1891, he struggled with depression, and was institutionalized in a mental asylum. His poetic breakthrough took place in 1893, when he published the first volume of poetry, Digte (Poems). A letter written to his brother in America in 1892, after he was released from the hospital, reveals his doubts concerning his life, as well as his opinion of America, which he sees a robust and adventurous country:

My illness presumably had deep and long roots. At the same time that all the depth and beauty I felt for music and my idea that nothing could be as worthwhile living for as that remains firm - my courage has disappeared on Norwegian soil. I am filled with doubt. It is as though it has become so distant again, even the desire to play is gone. No, America was no doubt just the country for bold plans. That was the country, robust and adventurous. ${ }^{49}$

His writing is considered to be a literary-historical marker of the $1890 \mathrm{~s}^{50}$, an expression of his restless soul, of a dreamer figure full of sensitivity and mysticism; it brings forth his predilect themes: loneliness, alienation, anxiety, in the form of free verse.

\footnotetext{
${ }^{48}$ Arestad, 1983:276-277.

${ }^{49}$ Ibid.:287-288

${ }^{50}$ Per Thomas Andersen, Norsk litteraturhistorie (Oslo: Universitetsforlaget, 2001): 297.
} 
Per Thomas Andersen considers Sigbjørn Obstfelder's poetry and Knut Hamsun's novels from the 1890s to be Norway's first modernistic literature. ${ }^{51}$ If Hamsun shifted the direction of the novel towards excessive naturalism, Obstfelder managed to mark the break of the Norwegian poets with the naturalistic verse. As Sverre Arestad remarked when comparing the American experiences of the two writers, Hamsun made use of the circumstances he had gone through, as his subject were the people, while Obstfelder could not make creative use of his experiences in America as they had no bearing on his artistic interests, since his interest lay in arts and ideas, leading him to mysticism. ${ }^{52}$ The emergence of modernity in Norwegian literature was already taking place, with Hamsun and Obstfelder as precursors that shared bitter immigrant experiences.

\section{Conclusions}

With more than 800,000 Norwegians that emigrated within a century (between 1825 and 1925), the Scandinavian country would be under the influence of the huge mobility that enhanced change in the homeland. Norwegian emigration reached such a massive scale as people were becoming more and more restless, more inclined to focus on personal achievement and less prone to follow the traditional way of life. Huge changes were generated in the Norwegian society, setting the scene for the emergence of modernity.

America letters tell the stories of those immigrants who unwillingly became agents of change in the Old World. Moreover, they are essential tools in the study of migration due to their focus on individual experiences, despite their dose of subjectivity. Two famous Norwegian writers, precursors of modernism in their homeland, exchanged such letters in which they depicted instances of their life in America.

Both Knut Hamsun and Sigbjørn Obstfelder had disappointing American experiences, although the first tackled it with irony and succeeded to overcome the less fortunate start in life, while the latter felt it more poignantly, as an erratic episode of his lonely life. Hence, their

\footnotetext{
51 P.T. Andersen, 2001:262

${ }^{52}$ Arestad, 1983:262-263.
} 
struggles in the land where modernity had already come would set their mark on their evolution as individuals, as writers.

\section{References}

Andersen, Arlow W. 'Knut Hamsun's America'. Norwegian-American Studies 23 (1967):175-203.

Andersen, Per Thomas. Norsk litteraturhistorie. Oslo: Universitetsforlaget, 2001.

Arestad, Sverre. 'Hamsun and America'. Norwegian-American Studies 24 (1970):148-192.

Arestad, Sverre. 'Sigbjørn Obstfelder and America'. Norwegian-American Studies 29 (1983):253-293.

Astrup Larsen, Hanna. Knut Hamsun. New York: Alfred A. Knopf, 1922.

Beyer, Harald. A History of Norwegian Literature, Translated and edited by Einar Haugen. New York: New York University Press for the American-Scandinavian Foundation, Fourth printing, 1979.

Blegen, Theodore C. Land of Their Choice: The Immigrants Write Home.

Minneapolis: The University of Minnesota Press, 1955.

Blegen, Theodore C. 'The Immigrant Image of America'. NorwegianAmerican Studies and Records 19 (1956):1-14.

Brumo, John and Furuseth, Sissel. Norsk litterære modernisme. Bergen: Fagbokforlaget, 2005.

Elliott, Bruce S., Gerber, David A. and Sinke, Suzanne M. 'Introduction'. Letters across Borders. The Epistolary Practices of International Migrants. New York: Palgrave Macmillan, Published in association with the Carleton Centre for the History of Migration, 2006.

Hamsun, Knut. The Cultural Life of Modern America, Edited and translated by Barbara Gordon Morgridge. Cambridge, Massachusetts: Harvard University Press, 1969.

Haugen, Einar Engvald. The Norwegian language in America: a study in bilingual behavior. Bloomington: Indiana University Press, 1969.

Krawatzek, Félix and Sasse, Gwendolyn. 'Integration and Identities: The Effects of Time, Migrant Networks, and Political Crises on Germans 
in the United States'. Comparative Studies in Society and History, 60(4) (2018): 1029-1065. doi:10.1017/S0010417518000373.

Larsen, Lars Frode. 'Knut Hamsuns <exodus>-Amerika-Oppholdet 18821884'. Nordlit 13 (2003):99-113. https://doi.org/10.7557/13.1945.

Lovoll, Odd S. The Promise of America. A History of the Norwegian-American People, Revised Edition, Minneapolis, London: University of Minnesota Press, 1999.

Mureșan, Ioana-Andreea. 'Deconstructing the American Dream: America Through Knut Hamsun's Eyes'. Studia UBB Philologia, LXII (3) (2017): 147-154.

Næss, Harald and McFarlane, James. Knut Hamsun: Selected Letters: Volume 1: 1879-98. London: Norvik Press, 1990.

Semmingsen, Ingrid. Norway to America. A History of the Migration, Translated by Einar Haugen. Minneapolis: University of Minnesota Press, 1978.

Skard, Sigmund. The United States in Norwegian History. Contributions in American Studies No. 26. Westport, Connecticut, London, England: Greenwood Press, Oslo: Universitetsforlaget, 1976.

Zempel, Solveig. In Their Own Words. Letters from Norwegian Immigrants. Minneapolis, London: University of Minnesota Press, The Norwegian-American Historical Association, 1991.

Østrem, Nils Olav. Norsk utvandringshistorie. Oslo: Det Norske Samlaget, 2006.

Øverland, Orm. The Western Home: A Literary History of Norwegian America. Northfield, Minnesota: Norwegian-American Historical Association, Distributed by University of Illinois Press, 1996. 